\title{
構造場と音響場の統一的直交因子の定式化と制御：開空間の場合*
}

\author{
貝塚勉*1, 田中信 雄*2
}

\section{Active Control of Both Vibration and Sound in Free Space}

\author{
Tsutomu KAIZUKA and Nobuo TANAKA*3 \\ ${ }^{* 3}$ Department of Aerospace Engineering, Tokyo Metropolitan University, \\ 6-6 Asahigaoka, Hino-shi, Tokyo, 191-0065 Japan
}

\begin{abstract}
Orthogonal contributors in terms of both structural kinetic energy and radiated acoustic power are derived for the purpose of simultaneous attenuation of both vibration and sound. The orthogonal contributors are referred to as "vibroacoustic modes". The vibroacoustic modes have eigenvalues and eigenvectors along with structural modes and radiation modes. The eigenvalues of the vibroacoustic modes indicate the vibroacoustic modes' contributions to the sum of the structural kinetic energy and radiated acoustic power. The eigenvectors of the vibroacoustic modes indicate the modal shapes of the vibroacoustic modes. The complex modal amplitudes of the vibroacoustic modes can be measured by filtering error signals from discrete structural sensors attached on a structure. It is found that the sum of the structural kinetic energy and radiated acoustic power can be estimated by the sum of the squared complex modal amplitudes of few of the vibroacoustic modes which have higher contributions (higher eigenvalues). This allows one to get a reduced order controller. To verify the validity of vibroacoustic modal control, numerical results relating to an isotropic plate in an infinite baffle are presented.
\end{abstract}

Key Words: Vibration Control, Noise Control, Sound and Acoustic, Radiation Mode

\section{1. 緒言}

振動する構造物は, 騷音を放射する。このとき, 静 肃化に関する議論は, 構造場と音響場に二分される. 構造場の静肃化とは, 振動の抑制であり, 音響場の静 肃化とは，騒音の抑制である，不幸にも，振動の抑制 は, 必ずしも騒音の抑制に直結しないし, 騒音の抑制 は, 必ずしも振動の抑制に直結しない[1][2]. 真の静肃 化を望むならば,構造場と音響場の統合的静肃化を志 向するべきであり, 振動だけを評価関数に置くのでは なく, 騒音だけを評価関数に置くのではなく, 振動と 騒音の和を評価関数に置くべきである.すなわち, 構 造物の運動エネルギと構造物から放射される音響パ ワーの和を評価関数に置くべきである.

制御系を設計する際, 評価関数に関する直交因子を 知ることは, 有意義である. 運動エネルギを評価関数 に置く場合, それに関する直交因子『構造モード』を 知ることは，当該制御系の合理的設計に役立つ $[3]-[11]$. 音響パワーを評価関数に置く場合, それに関する直交 因子『放射モード』を知ることは, 当該制御系の合理

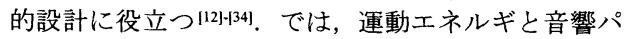
ワーの和を評価関数に置く場合, それに関する直交因 子とは，何なのだろうか.

* 原稿受付 2006 年 11 月 15 日.

*1 准員, 首都大学東京大学院システムデザイン研究科 (画 1910065 日野市旭が丘 6-6), 日本学術振興会特別研究員 DCI.

*2 正員, フェロー, 首都大学東京システムデザイン学部.

E-mail : ntanaka@cc.tmit.ac.jp
本論文の第一の目的は, 運動エネルギと音響パワー の和に関する直交因子『構造音響モード(vibroacoustic mode)』の定式化である. 構造モードや放射モードと 同様, 構造音響モードは, 固有值と固有ベクトルを持 つ. その固有値は, 運動エネルギと音響パワーの和に 対する寄与度を示し, その固有ベクトルは, モード形 状を示す.

本論文の第二の目的は,構造音響モードを評価関数 に置く制御系『構造音響モード制御 (vibroacoustic modal control)』の提案である. 構造音響モードのモー ド振幅は, 構造物上の各点における複素速度を計測 し，それら計測信号を特殊な空間フィルタに通すこと によって算出される.ここで, 寄与度の高い (固有值 の大きい)構造音響モードだけを抽出し, それを評価 関数に置く.すると, 制御系の次数を抑えつつ, 運動 エネルギと音響パワーの和を近似的に最小化できる.

第2章では, 任意の構造物を対象として一般論を展 開し, 構造音響モードを定式化した後, 構造音響モー ド制御を提案する. 第3 章では, 無限大バフル内の周 辺単純支持矩形平板を対象として数值解析を行い, 構 造音響モードの奇与度とモード形状を明らかにする。 また, 構造音響モード制御の適用前後における運動エ ネルギと音響パワーを数值解析し, 当該制御法の有効 性を検証する. 第4章では, 本論文の成果を総括する. 


\section{2. 一般理論}

本章では,任意の構造物を対象として一般論を展開 し,構造物の運動エネルギと構造物から放射される音 響パワーの和に関する直交因子を定式化する．続い て, 当該因子の計測制御法を提案し, その有効性につ いて解説する.

\section{1 構造音響モード 本節では, 構造物の運動} エネルギと構造物から放射される音響パワーの和に関 する直交因子を導出する.構造物の表面を有限個の要 素に分割して考え, 構造物の運動エネルギ $E(\omega)^{[16] を ~}$ 次式に定義する.

$E(\omega)=\mathbf{v}^{H}(\omega) \mathbf{M v}(\omega)$

ただし，

$\mathbf{v}(\omega)=\operatorname{col}\left[v\left(\mathbf{r}_{1}, \omega\right) \quad \cdots \quad v\left(\mathbf{r}_{M}, \omega\right)\right] \in \mathbb{C}^{M \times 1}$

$\mathbf{M}=\frac{\Delta S}{2} \operatorname{diag}\left[\rho\left(\mathbf{r}_{1}\right) h\left(\mathbf{r}_{1}\right) \quad \cdots \quad \rho\left(\mathbf{r}_{M}\right) h\left(\mathbf{r}_{M}\right)\right] \in \mathbb{R}^{M \times M}$ (3)

ただし, $\mathbf{r}_{m}$ を $m$ 番目の要素の中心座標, $v\left(\mathbf{r}_{m}, \omega\right)$ を複 素速度, $\rho\left(\mathbf{r}_{m}\right)$ を密度, $h\left(\mathbf{r}_{m}\right)$ を厚さ, $M$ を要素の総 数, $\omega$ を角振動数, $H$ を複素共役転置, $\Delta S$ を各要素の表 面積（簡単のため, 各要素の表面積を一定と仮定し た.), colを列ベクトル, diag を対角マトリクス, $\mathbb{C} を$ 複素数を要素に持つマトリクス, $\mathbb{R}$ を実数を要素に持 つマトリクスとする.

また, 構造物から放射される音響パワー $W(\omega)^{[17] を ~}$ 次式に定義する.

$W(\omega)=\mathbf{v}^{H}(\omega) \mathbf{R}(\omega) \mathbf{v}(\omega)$

ただし，

$\mathbf{R}(\omega)=\frac{\Delta S}{2} \operatorname{Re}[\mathbf{Z}(\omega)] \in \mathbb{R}^{M \times M}$

$\mathbf{Z}(\omega) \in \mathbb{C}^{M \times M}$ は, 音響インピーダンス・マトリクスで あり，正定な対称マトリクスである ${ }^{[17]}$. なお, $\operatorname{Re}[*]$ を*の実数部とする.

いま, 構造場と音響場の統合的静肃化を志向して, 運動エネルギと音響パワーの和を評価関数 $J(\omega)$ とし て定義する.

$J(\omega)=\alpha(\omega) E(\omega)+W(\omega)$

ただし， $\alpha(\omega)$ は, 正数であり, 運動エネルギと音響パ ワーの相対的な重みを決める係数として機能する.式 (1),(4)を式(6)に代入すると, 次式を得る.
$J(\omega)=\mathbf{v}^{H}(\omega)\{\alpha(\omega) \mathbf{M}+\mathbf{R}(\omega)\} \mathbf{v}(\omega)$

式(7) $[[\alpha(\omega) \mathbf{M}+\mathbf{R}(\omega)]$ は, 正定な実対称マトリク スであるため, 次式のように対角化できる.

$\mathbf{Q}^{T}(\omega)\{\alpha(\omega) \mathbf{M}+\mathbf{R}(\omega)\} \mathbf{Q}(\omega)=\Lambda(\omega) \in \mathbb{R}^{M \times M}$

ただし, $\boldsymbol{\Lambda}(\omega)$ を $\{\alpha(\omega) \mathbf{M}+\mathbf{R}(\omega)\}$ の固有値から成る 対角マトリクス, $\mathbf{Q}(\omega) \in \mathbb{R}^{M \times M} を\{\alpha(\omega) \mathbf{M}+\mathbf{R}(\omega)\}$ の固有べクトルから成る直交マトリクス, ${ }^{T}$ を転置と する.式(8)の通り, $\Lambda(\omega)$ と $\mathbf{Q}(\omega)$ は, 重み係数 $\alpha(\omega)$ に依存する. 式 $(8)$ を式(7)へ代入し, 次式を得る.

$J(\omega)=\mathbf{y}^{H}(\omega) \Lambda(\omega) \mathbf{y}(\omega)$

ただし，

$\mathbf{y}(\omega)=\mathbf{Q}^{T}(\omega) \mathbf{v}(\omega) \in \mathbb{C}^{M \times 1}$

式(9)の通り, $\mathbf{y}(\omega)$ は, 評価関数 $J(\omega)$ に関する直交因 子である，本論文では，当該因子のことを構造音響 モードと呼ぶ. $\Lambda(\omega)$ を成す固有值は, 構造音響モー ドの評価関数 $J(\omega)$ に対する寄与度を示し, $\mathbf{Q}(\omega)$ を成 す固有ベクトルは, 構造音響モ一ドのモード形状を示 し, $\mathbf{y}(\omega)$ を成す要素は, 構造音響モードのモード振幅 を示す.

ところで, 構造物の面密度 $\rho\left(\mathbf{r}_{m}\right) h\left(\mathbf{r}_{m}\right)$ を一定と仮 定した場合, 式(8)は, 次式に書き換えられる.

$\mathbf{Q}^{T}(\omega)\left\{\frac{\Delta S \rho h \alpha(\omega)}{2} \mathbf{I}_{M}+\mathbf{R}(\omega)\right\} \mathbf{Q}(\omega)=\Lambda(\omega)$

ただし, $\mathbf{I}_{M} \in \mathbb{R}^{M \times M}$ を単位マトリクスとする. 式(11) は, 次式に展開できる.

$\frac{\Delta S \rho h \alpha(\omega)}{2} \mathbf{I}_{M}+\mathbf{\Omega}(\omega)=\Lambda(\omega)$

ただし

$\mathbf{Q}^{T}(\omega) \mathbf{R}(\omega) \mathbf{Q}(\omega)=\mathbf{\Omega}(\omega)$

ただし, $\mathbf{\Omega}(\omega)$ を $\mathbf{R}(\omega)$ の固有值から成る対角マトリ クスとする. 式(12)の通り, $\Lambda(\omega)$ は, 重み係数 $\alpha(\omega)$ に依存する.一方, 式(13)の通り, $\mathbf{Q}(\omega)$ は, 重み係数 $\alpha(\omega)$ に依存しない. さて, 文献[17]の通り, $\Omega(\omega)$ を 成す固有值は, 放射モードの放射効率 (正確には, 放 射効率に比例する值であるが, 便宜上, 放射効率と呼 ぶ.）を示し，式(13)を満たす直交マトリクス $\mathbf{Q}(\omega)$ を成す固有ベクトルは, 放射モードのモード形状を示 す. それ故, 構造物の面密度を一定とした場合, 構造 
音響モードの評価関数 $J(\omega)$ に対する寄与度は, 放射 モードの放射効率に $\Delta S \rho h \alpha(\omega) / 2$ を加えたものに等 しく, 構造音響モードのモード形状は, 放射モードの モード形状と一致する.

\section{2 構造音響モード制御 本節では, 構造音響} モードの計測制御法を提案する. 式(10)の通り, 構造 音響モードのモード振幅 $\mathbf{y}(\omega)$ は, 計測した複素速度 $\mathbf{v}(\omega)$ を空間フィルタ $\mathbf{Q}(\omega)$ に通すことによって算出 できる.いま, $\Lambda(\omega)$ を成す固有值同士の大小関係を 考慮して,より大きい固有值を持つ構造音響モードか ら順に 1 次, 2 次, 3 次, $\cdots, M$ 次とモード次数を割り振 ることにする.前述の通り, $\Lambda(\omega)$ を成す固有値は, 構 造音響モードの評価関数 $J(\omega)$ に対する寄与度を示し ている.したがって, 低次の構造音響モードほど, 評 価関数 $J(\omega)$ に対して高い寄与度を持つことになる. ここで, 特に寄与度の高い $\tilde{M} \leq M$ 次以下の構造音響 モードだけを抽出し,これを評価関数 $\tilde{J}(\omega)$ として定 義する.

$\tilde{J}(\omega)=\tilde{\mathbf{y}}^{H}(\omega) \tilde{\Lambda}(\omega) \tilde{\mathbf{y}}(\omega)$

ただし，

$$
\tilde{\mathbf{y}}(\omega)=\tilde{\mathbf{Q}}^{T}(\omega) \mathbf{v}(\omega) \in \mathbb{C}^{\tilde{M} \times 1}
$$

$\tilde{\Lambda}(\omega) \in \mathbb{R}^{\tilde{M} \times \tilde{M}}$ を $\tilde{M}$ 次以下の固有值から成る対角マト リクス, $\tilde{\mathbf{Q}}(\omega) \in \mathbb{R}^{M \times \tilde{M}}$ を $\tilde{M}$ 次以下の固有ベクトルか ら成るマトリクスとする. $\tilde{J}(\omega)$ を評価関数に置く制 御系の次数は, $J(\omega)$ を評価関数に置く制御系の次数 よりも少なくて済む. 本論文では, このような制御系 を構造音響モード制御と呼ぶ. 図 1 は, 構造音響モー ド制御の概念図である.

続いて, 評価関数 $\tilde{J}(\omega)$ を最小化する最適フィード フォワード制御則を導出する. 分布外乱力 $f_{\mathrm{p}}(\mathbf{r}, \omega)$ と 集中制御力 $f_{i}(\omega)$ を想定したとき, 複素速度 $\mathbf{v}(\omega)$ は, 次式で記述される.

$$
\begin{aligned}
& \mathbf{v}(\omega)=\Psi^{T} \mathbf{Y}(\omega)\left\{\int_{S} \Psi(\mathbf{r}) f_{\mathrm{p}}(\mathbf{r}, \omega) d \mathbf{r}+\Psi_{\mathrm{s}} \mathbf{f}_{\mathrm{s}}(\omega)\right\} \\
& \text { ただし， } \\
& \Psi=\left[\begin{array}{lll}
\Psi\left(\mathbf{r}_{1}\right) & \cdots & \psi\left(\mathbf{r}_{M}\right)
\end{array}\right] \in \mathbb{R}^{N \times M} \\
& \Psi_{\mathrm{s}}=\left[\begin{array}{lll}
\psi\left(\mathbf{r}_{1}\right) & \cdots & \psi\left(\mathbf{r}_{I}\right)
\end{array}\right] \in \mathbb{R}^{N \times I} \\
& \Psi(\mathbf{r})=\operatorname{col}\left[\psi_{1}(\mathbf{r}) \quad \cdots \quad \psi_{N}(\mathbf{r})\right] \in \mathbb{R}^{N \times 1} \\
& \mathbf{Y}(\omega)=\operatorname{diag}\left[Y_{1}(\omega) \quad \cdots \quad Y_{N}(\omega)\right] \in \mathbb{C}^{N \times N} \\
& Y_{n}(\omega)=\frac{j \omega}{\left[\omega_{n}^{2}-\omega^{2}+j \eta_{n} \omega_{n} \omega\right]} \\
& \mathbf{f}_{\mathrm{s}}(\omega)=\operatorname{col}\left[f_{1}(\omega) \quad \cdots \quad f_{I}(\omega)\right] \in \mathbb{C}^{I \times 1} \\
& \psi_{n}(\mathbf{r}) \text { を } n \text { 次構造モードのモード関数, } \omega_{n} \text { を } n \text { 次構造 }
\end{aligned}
$$

$$
\begin{aligned}
& \tilde{J}(\omega)=\mathbf{f}_{\mathrm{s}}^{H}(\omega) \mathbf{A}(\omega) \mathbf{f}_{\mathrm{s}}(\omega)+\mathbf{f}_{\mathrm{s}}^{H}(\omega) \mathbf{b}(\omega) \\
& +\mathbf{b}^{H}(\omega) \mathbf{f}_{\mathrm{s}}(\omega)+c(\omega) \\
& \text { ただし, }
\end{aligned}
$$

$$
\begin{aligned}
& \mathbf{A}(\omega)=\Psi_{s}^{T} \mathbf{Y}^{*}(\omega) \Psi \tilde{\mathbf{Q}}(\omega) \tilde{\Lambda}(\omega) \\
& \tilde{\mathbf{Q}}^{T}(\omega) \Psi^{T} \mathbf{Y}(\omega) \Psi_{\mathrm{s}} \in \mathbb{R}^{I \times I} \\
& \mathbf{b}(\omega)=\Psi_{\mathrm{s}}^{T} \mathbf{Y}^{*}(\omega) \Psi \tilde{\mathbf{Q}}(\omega) \tilde{\Lambda}(\omega) \\
& \tilde{\mathbf{Q}}^{T}(\omega) \Psi^{T} \mathbf{Y}(\omega) \int_{S} \Psi(\mathbf{r}) f_{\mathrm{p}}(\mathbf{r}, \omega) d \mathbf{r} \in \mathbb{R}^{I \times 1} \\
& c(\omega)=\int_{S} \Psi^{T}(\mathbf{r}) f_{\mathrm{p}}^{*}(\mathbf{r}, \omega) d \mathbf{r} \mathbf{Y}^{*}(\omega) \Psi \tilde{\mathbf{Q}}(\omega) \tilde{\Lambda}(\omega) \\
& \tilde{\mathbf{Q}}^{T}(\omega) \Psi^{T} \mathbf{Y}(\omega) \int_{S} \Psi(\mathbf{r}) f_{\mathrm{p}}(\mathbf{r}, \omega) d \mathbf{r}
\end{aligned}
$$

なお, *を複素共役とする. 式(23)の形から, 評価関数 $\tilde{J}(\omega)$ を最小化する最適フィードフォワード制御則 は, 次式となる ${ }^{[35]}$.

$$
\mathbf{f}_{s}(\omega)=-\mathbf{A}^{-1}(\omega) \mathbf{b}(\omega)
$$

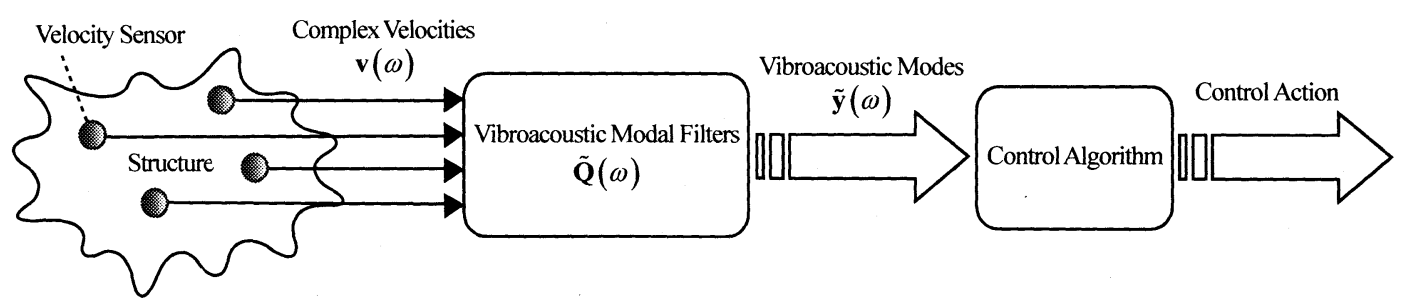

Fig. 1. Aschematic diagram of vibroacoustic modal control with the condensation of the error signals via the vibroacoustic modal filters. 


\section{3. ケース・スタディ}

本章では, 図2に示される無限大バフル内の周辺単 純支持矩形平板を例に挙げ,構造音響モードの寄与度 (固有値) とモード形状（固有ベクトル）の数值解析 結果を提示する.また, 構造音響モード制御を平板に 適用した前後の運動エネルギと音響パワーの数值解析 結果を提示し, 当該制御法の有効性を検証する.

3. 1 解析モデル 本節では, 解析モデルを記述 する. 周辺単純支持矩形平板の構造モード関数は, 次 式で与えられる[36].

$\psi_{n}(\mathbf{r})=\psi_{n_{x}, n_{y}}(x, y)=\sqrt{\frac{4}{L_{x} L_{y} \rho h}} \sin \frac{n_{x} \pi x}{L_{x}} \sin \frac{n_{y} \pi y}{L_{y}}$

ただし， $L_{x}$ を平板の $x$ 方向の長さ, $L_{y}$ を平板の $y$ 方向 の長さとする. 平板の厚みと密度は, 一定とした.こ のときの固有角振動数は, 次式で与えられる ${ }^{361}$.

$\omega_{n}=\omega_{n_{x}, n_{y}}=\sqrt{\frac{D}{\rho h}}\left\{\left(\frac{n_{x} \pi}{L_{x}}\right)^{2}+\left(\frac{n_{y} \pi}{L_{y}}\right)^{2}\right\}$

$D$ は, 平板の曲げ剛性であり, 次式で与えられる.

$D=\frac{E h^{3}}{12\left(1-v^{2}\right)}$

$E$ を平板のヤング率, $v$ を平板のポアソン比とする. 平板の諸元は, $L_{x}=0.38 \mathrm{~m}, L_{y}=0.30 \mathrm{~m}, h=0.001 \mathrm{~m}$, $\rho=2720 \mathrm{~kg} / \mathrm{m}^{3}, E=71 \times 10^{9} \mathrm{~Pa}, v=0.33, N=6 \times 6$ $=36, \eta_{n}=0.002, M=10 \times 10=100$ とした.

また, 無限大バフルを想定した場合, 音響インピー ダンス・マトリクス $\mathbf{Z}(\omega)$ の $m_{A}$ 行 $m_{B}$ 列 $Z_{m_{A}, m_{B}}(\omega)$ は, 次式で与えられる ${ }^{[17]}$.

$$
Z_{m_{A}, m_{B}}(\omega)=\frac{j \omega \rho_{0} S}{2 \pi\left|\mathbf{r}_{m_{A}}-\mathbf{r}_{m_{B}}\right|} e^{-j k\left|\mathbf{r}_{m_{A}}-\mathbf{r}_{m_{B}}\right|}
$$

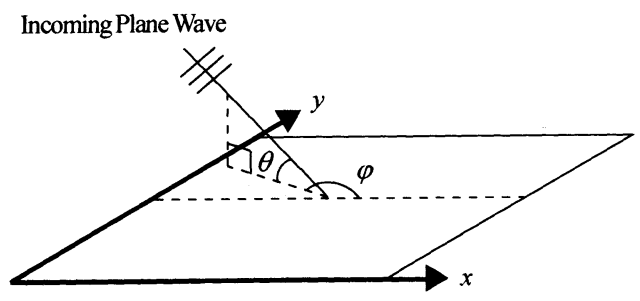

Fig. 2. A simply supported rectangular plate on which external plane wave is incident with the angles elevation $\theta$ and azimuth $\varphi$.
ただし, $\rho_{0}$ を媒質密度, $k=\omega / c_{0}$ を波数, $c_{0}$ を音速とす る. 音響媒質の諸元は, $\rho_{0}=1.21 \mathrm{~kg} / \mathrm{m}^{3}, c_{0}=343 \mathrm{~m} / \mathrm{s}$ とした。

3. 2 構造音響モードの寄与度とモード形状 本 節では, 構造音響モードの寄与度 (固有值) とモード 形状 (固有ベクトル) の数值解析結果を提示する. 式 (28)の通り, 平板の面密度は, 一定である. したがっ て, 式(12)の通り, 構造音響モードの寄与度は, 重み 係数 $\alpha(\omega)$ に依存する. 一方, 式(13)の通り, 構造音 響モードのモード形状は, 重み係数 $\alpha(\omega)$ に依存しな い. 本解析においては, 簡単のため, 重み係数 $\alpha(\omega)$ を周波数に関わらず一定とし， $\alpha=1.0$ に設定した.式 (6)の通り,このときの構造音響モードは, 運動エネル ギと音響パワーを同等に評価した場合のものとなる. 仮に重み係数を1より大きい値に設定すれば,このと きの構造音響モードは, 運動エネルギに重きを置いて 評価した場合のものとなる.また，仮に重み係数を 1 より小さい值に設定すれば,このときの構造音響モー ドは, 音響パワーに重きを置いて評価した場合のもの となる。

図3は, 1次から4次までの構造音響モードの寄与度 と併せて，1次から4次までの放射モードの放射効率 を示している. 式(12)にて示した通り, 構造音響モー ドの寄与度は, 放射モードの放射効率に $\Delta S \rho h \alpha / 2$ を 加えた值となっている.また, 低次構造音響モードの 寄与度は, 高次構造音響モードの寄与度を圧倒してい る. したがって, 評価関数 $J(\omega)$ は, 少数の低次構造 音響モードから成る評価関数 $\tilde{J}(\omega)$ によって十分に近 似されるはずである。

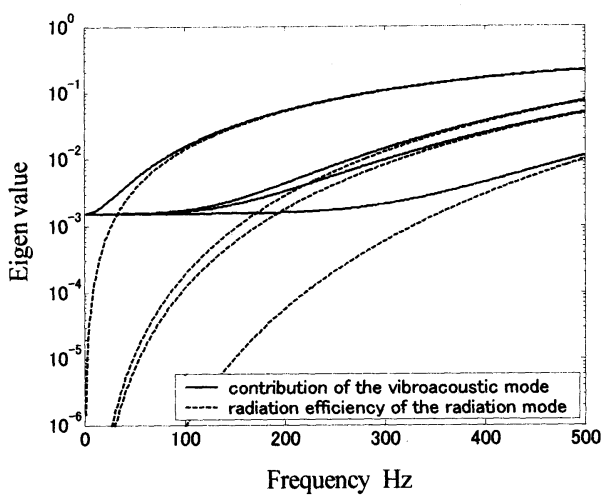

Fig. 3. Contributions to the sum of the structural kinetic energy and acoustic power from the first four vibroacoustic modes with $\alpha=1.0$, and radiation efficiencies of the first four radiation modes. 
図4は, 1次から4次までの構造音響モードのモード 形状を示している. ただし, 解析対象の周波数を $100 \mathrm{~Hz}$ とした.1次の構造音響モードのモード形状は, 単極を示している. 2次, 3次の構造音響モードのモー ド形状は, 二重極を示している.4次の構造音響モ一 ドのモード形状は, 四重極を示している.なお, 式(13) にて示した通り,構造音響モードのモード形状は, 放 射モードのモード形状と一致する.

3. 3 構造音響モード制御 本節では, 構造音響 モード制御を平板に適用した前後の運動エネルギおよ び音響パワーの数值解析結果を提示する. 図 2 の通 り, 外乱は, 平板に対して仰角 $\theta=\pi / 4$, 水平角 $\varphi=\pi / 4$ で入射する音圧振幅 $1 \mathrm{~Pa}$ の平面波と仮定した.
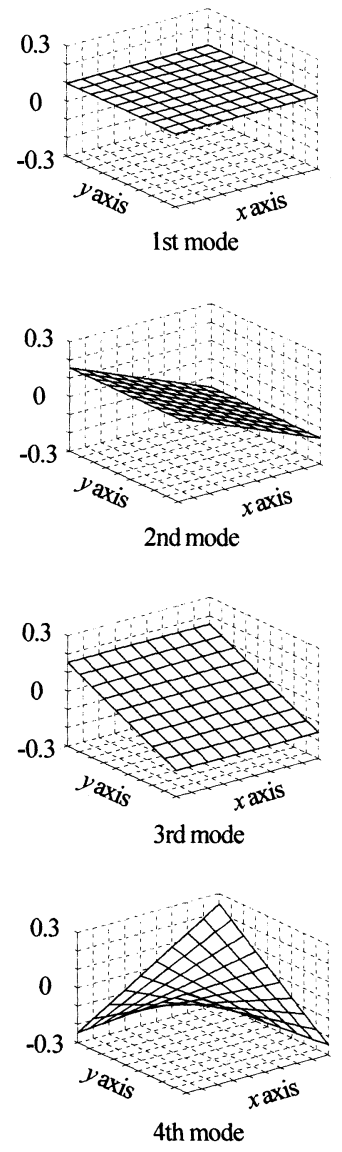

Fig. 4. Mode shapes of the first four vibroacoustic modes with $\alpha=1.0$ and $100 \mathrm{~Hz}$.
図 5 の通り, 複素速度の計測点は, 100 個の要素の各 中心座標に置き, 集中制御力は, 低次構造モードの節 と重ならないよう座標 $\left(L_{x} / 10, L_{y} / 10\right)$ に置いた. 重み 係数は, 前節と同様に $\alpha=1.0$ とした.

前節にて述べた通り, 評価関数 $J(\omega)$ は, 少数の低 次構造音響モードから成る評価関数 $\tilde{J}(\omega)$ によって十 分に近似されるはずである. 図6は, 外乱のみ作用し ている場合の $J(\omega)$ と併せて, 1 次から 16次までの構 造音響モードから成る $\tilde{J}(\omega)$ を示している. 図の通 り, 両者の周波数特性は, 殆ど一致している.すなわ ち, $J(\omega)$ は, 1次から16次までの構造音響モードから 成る $\tilde{J}(\omega)$ をもって十分に近似できる.つまり, 運動 エネルギと音響パワーの和の最小化制御は, 16 次の 制御系によって近似的に実行できる.

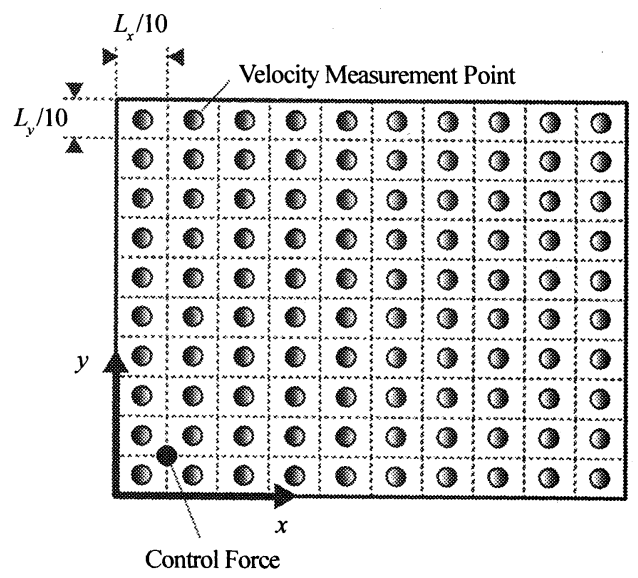

Fig. 5. A rectangular plate with locations of the velocity measurements and the control force.

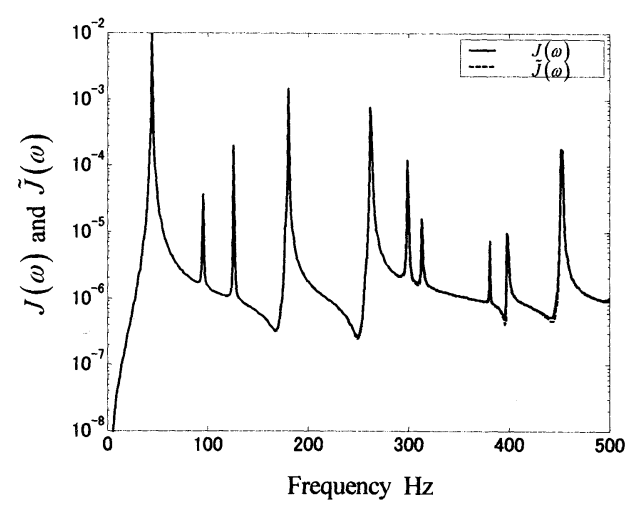

Fig. 6. Frequency characteristics of $J(\omega)$ and $\tilde{J}(\omega)$ which contains the first sixteen vibroacoustic modes, with $\alpha=1.0$. 
図7は, 各種制御を講じた前後の運動エネルギを示 しており, 図 8 は, 各種制御を講じた前後の音響パ ワーを示している.解析対象とした制御系は, 運動エ ネルギの最小化制御 (付録 1 参照)，音響パワーの最小 化制御 (付録 2 参照), 1 次から 16 次までの構造音響 モードから成る評価関数 $\tilde{J}(\omega)$ の最小化制御 (構造音 響モード制御)である.複素速度計測点および集中制
御力の設定は, いずれの制御系も図5に準じている. 既述の通り, 運動エネルギの最小化は, 音響パワーの 抑制に直結していない. また, 音響パワーの最小化 は, 運動エネルギの抑制に直結していない.これに対 し, 構造音響モード制御は, 運動エネルギの抑制と音 響パワーの抑制を重み係数 $\alpha=1.0$ というバランスを もって統合的に処理している.

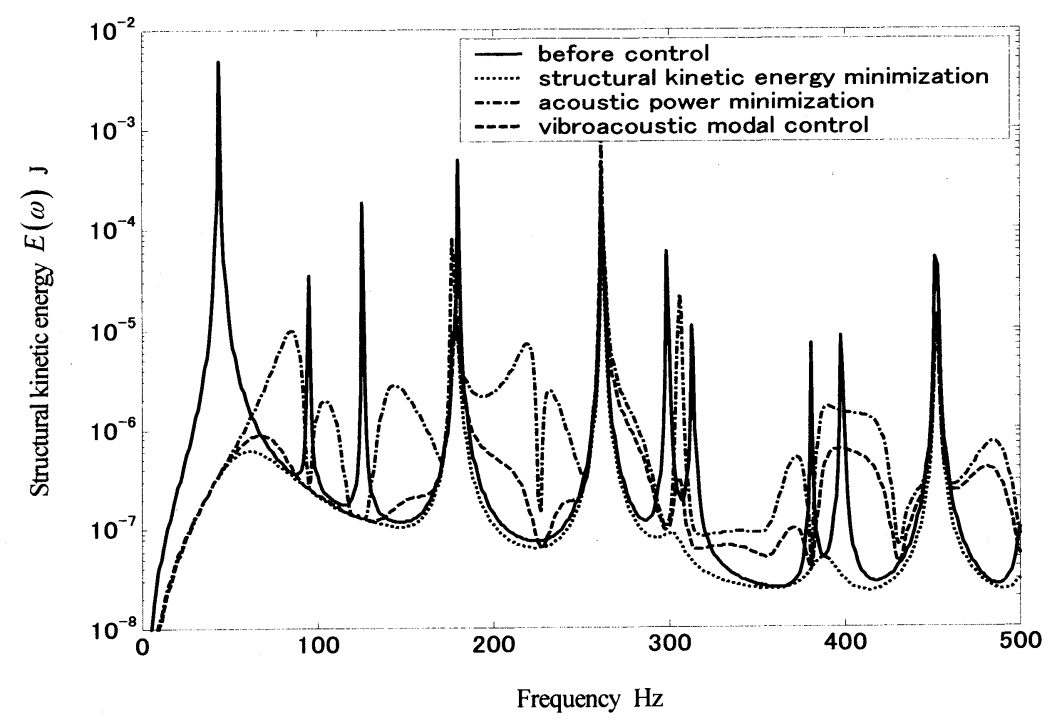

Fig. 7. Structural kinetic energy of the plate before and after structural kinetic energy minimization, acoustic power minimization, and vibroacoustic modal control with $\alpha=1.0$.

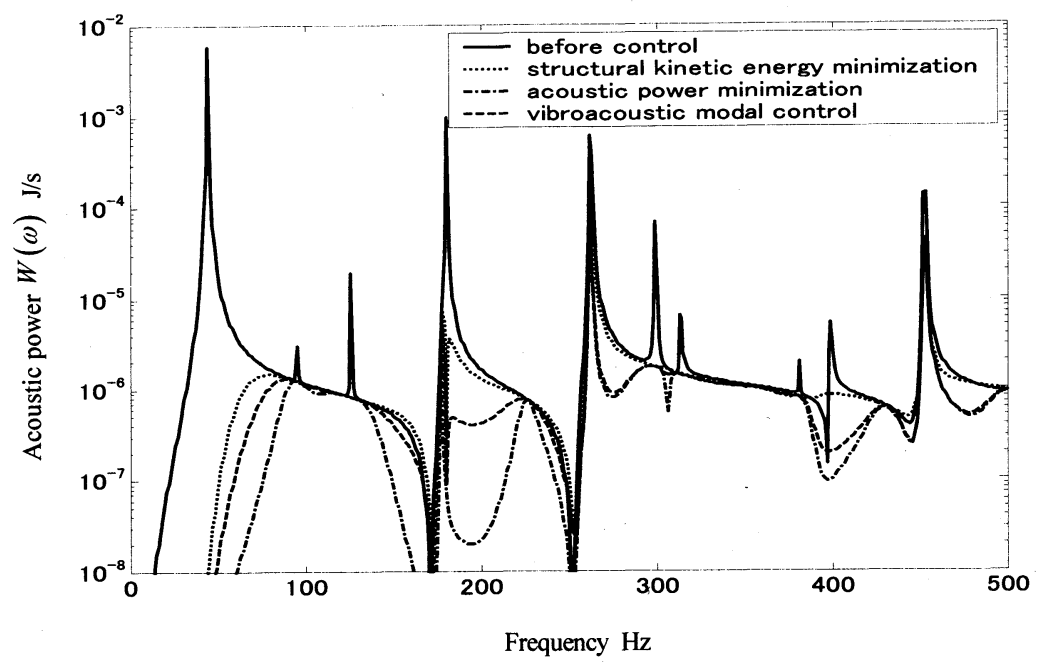

Fig. 8. Acoustic power radiated from the plate before and after structural kinetic energy minimization, acoustic power minimization, and vibroacoustic modal control with $\alpha=1.0$. 


\section{4. 結言}

構造場と音響場の統合的静肃化を目的として,構造 物の運動エネルギと構造物から放射される音響パワー の和に関する直交因子『構造音響モード(vibroacoustic mode)』を定式化した．構造モードや放射モードと同 様，構造音響モードは，固有値と固有ベクトルを持 つ. その固有値は, 運動エネルギと音響パワーの和に 対する寄与度を示し, その固有ベクトルは, モード形 状を示す.なお, 構造物の面密度を一定と仮定した場 合，構造音響モードのモード形状は，放射モードの モード形状と一致する.

構造音響モードのモード振幅は, 構造物上の各点に おける複素速度を計測し，それら計測信号を特殊な空 間フィルタに通すことによって算出される.寄与度の 高い構造音響モードだけを抽出し, それを評価関数に 置くことで, 制御系の次数を抑えつつ, 運動エネルギ と音響パワーの和を近似的に最小化できる.このよう に構造音響モードを評価関数に置く制御系を『構造音 響モード制御(vibroacoustic modal control)』と呼ぶ.

無限大バフル内の周辺単純支持矩形平板を例として 数值解析を行い, 構造音響モードの寄与度とモード形 状を明らかにした。また, 構造音響モード制御を平板 に適用した前後の数値解析を行い, 運動エネルギと音 響パワーの統合的静肃化を確認した. なお,この解析 では, 構造音響モード振幅の算出のため, 構造物上の 100 点における複素速度の計測を前提とした。ただ し, 評価関数は, 100 個の複素速度ではなく, 寄与度 の高い順に抽出された16個の構造音響モード振幅で あった，すなわち，当該制御系の次数は，100ではな く，僅か16であった。

付録 $1:$ 運動エネルギの最小化制御 式(16)を式(1)に代入すると, 次式を得る.

$E(\omega)=\mathbf{f}_{\mathrm{s}}^{H}(\omega) \mathbf{A}_{E}(\omega) \mathbf{f}_{\mathrm{s}}(\omega)+\mathbf{f}_{\mathrm{s}}^{H}(\omega) \mathbf{b}_{E}(\omega)$ $+\mathbf{b}_{E}{ }^{H}(\omega) \mathbf{f}_{\mathbf{s}}(\omega)+c_{E}(\omega)$

ただし，

$$
\begin{aligned}
& \mathbf{A}_{E}(\omega)=\Psi_{\mathrm{s}}^{T} \mathbf{Y}^{*}(\omega) \Psi \mathbf{M} \Psi^{T} \mathbf{Y}(\omega) \Psi_{\mathrm{s}} \in \mathbb{R}^{I \times I} \\
& \mathbf{b}_{E}(\omega)=\Psi_{\mathrm{s}}^{T} \mathbf{Y}^{*}(\omega) \Psi \mathbf{M} \\
& \Psi^{T} \mathbf{Y}(\omega) \int_{S} \Psi(\mathbf{r}) f_{\mathrm{p}}(\mathbf{r}, \omega) d \mathbf{r} \in \mathbb{R}^{I \times 1} \\
& c_{E}(\omega)=\int_{S} \Psi^{T}(\mathbf{r}) f_{\mathrm{p}}^{*}(\mathbf{r}, \omega) d \mathbf{r} \mathbf{Y}^{*}(\omega) \Psi \mathbf{M} \\
& \Psi^{T} \mathbf{Y}(\omega) \int_{S} \Psi(\mathbf{r}) f_{\mathrm{p}}(\mathbf{r}, \omega) d \mathbf{r}
\end{aligned}
$$

式 (A1)の形から, 運動エネルギを最小化する最適 フィードフォワード制御則は，次式となる ${ }^{[35]}$.

$$
\mathbf{f}_{\mathrm{s}}(\omega)=-\mathbf{A}_{E}^{-1}(\omega) \mathbf{b}_{E}(\omega)
$$

\section{付録 2 : 音響パワーの最小化制御}

式(16)を式(4)に代入すると，次式を得る。

$$
\begin{aligned}
& W(\omega)=\mathbf{f}_{\mathrm{s}}{ }^{H}(\omega) \mathbf{A}_{W}(\omega) \mathbf{f}_{\mathrm{s}}(\omega)+\mathbf{f}_{\mathrm{s}}{ }^{H}(\omega) \mathbf{b}_{W}(\omega) \\
& +\mathbf{b}_{W}{ }^{H}(\omega) \mathbf{f}_{\mathrm{s}}(\omega)+c_{W}(\omega) \\
& \text { ただし, }
\end{aligned}
$$$$
\mathbf{A}_{W}(\omega)=\Psi_{s}{ }^{T} \mathbf{Y}^{*}(\omega) \Psi \mathbf{R} \Psi^{T} \mathbf{Y}(\omega) \Psi_{s} \in \mathbb{R}^{I \times I}
$$$$
\mathbf{b}_{W}(\omega)=\Psi_{\mathrm{s}}^{T} \mathbf{Y}^{*}(\omega) \Psi \mathbf{R}
$$$$
\Psi^{T} \mathbf{Y}(\omega) \int_{S} \Psi(\mathbf{r}) f_{\mathrm{p}}(\mathbf{r}, \omega) d \mathbf{r} \in \mathbb{R}^{I \times 1}
$$$$
c_{W}(\omega)=\int_{S} \Psi^{T}(\mathbf{r}) f_{\mathrm{p}}^{*}(\mathbf{r}, \omega) d \mathbf{r} \mathbf{Y}^{*}(\omega) \Psi \mathbf{R}
$$$$
\Psi^{T} \mathbf{Y}(\omega) \int_{S} \Psi(\mathbf{r}) f_{\mathrm{p}}(\mathbf{r}, \omega) d \mathbf{r}
$$

式(A6)の形から, 音響パワーを最小化する最適フィー ドフォワード制御則は, 次式となる ${ }^{335]}$.

$$
\mathbf{f}_{s}(\omega)=-\mathbf{A}_{W}{ }^{-1}(\omega) \mathbf{b}_{W}(\omega)
$$

\section{謝辞}

本研究は, 日本学術振興会特別研究員奨励費の補助 を受け，遂行されたものである.

\section{文献}

[1] S. D. Snyder and C. H. Hansen, "Mechanisms of active noise control by vibration sources", J. Sound Vib. 147, (1991), pp. 519-525.

[2] J. Pan, S. D. Snyder, C. H. Hansen, and C. R. Fuller, "Active control of far-field sound radiated by a rectangular panel: A general analysis", J. Acoust. Soc. Am. 91, (1992), pp. 2056-2066.

[3] M. J. Balas, "Feedback control of flexible systems", IEEE Trans. Autom. Control 23, (1978), pp. 673-679.

[4] J. N. Aubrun, "Theory of the control of structures by lowauthority controllers", J. Guid. Control 3, (1980), pp. 444451.

[5] L. Meirovitch, H. Baruh, and H. Oz, "A comparison of control techniques for large flexible systems", J. Guid. Control Dyn. 6, (1983), pp. 302-310.

[6] D. R. Morgan, "An adaptive modal-based active control system", J. Acoust. Soc. Am. 89, (1990), pp. 248-256.

[7] R. L. Clark, "Adaptive feedforward modal space control", J. Acoust. Soc. Am. 98, (1995), pp. 2639-2650. 
[8] N. Tanaka, Y. Kikushima, and N. J. Fergusson, "Onedimensional distributed modal sensors and the active modal control for planar structures", J. Acoust. Soc. Am. 104, (1998), pp. 217-225.

[9] C. Mei, B. R. Mace, and R. W. Jones, "Hybrid wave/mode active vibration control", J. Sound Vib. 247, (2001), pp. 765-784.

[10] S. D. Snyder, "Active control: A bigger microprocessor is not always enough", Noise Control Eng. J. 49, (2001), pp. 21-29.

[11] S. J. Elliott, "Distributed control of sound and vibration", Noise Control Eng. J. 53, (2005), pp. 165-181.

[12] G. V. Borgiotti, "The power radiated by a vibration body in an acoustic fluid and its determination from boudary measurements", J. Acoust. Soc. Am. 88, (1990), pp. 1884-1893. [13] W. T. Baumann, W. R. Saunders, and H. H. Robertshaw, "Active suppression of acoustic radiation from impulsively excited structures", J. Acoust. Soc. Am. 90, (1991), pp. 32023208.

[14] K. A. Cunefare, "The minimum multimodal radiation efficiency of baffled finite beams", J. Acoust. Soc. Am. 90, (1991), pp. 2521-2529.

[15] K. Naghshineh and G. H. Koopmann, "Material tailoring of structures to achieve minimum radiation condition", $J$. Acoust. Soc. Am. 92, (1992), pp. 841-855.

[16] S. D. Snyder and N. Tanaka, "On feedforward active control of sound and vibration using vibration error signals", J. Acoust. Soc. Am. 94, (1993), pp. 2181-2193.

[17] S. J. Elliott and M. E. Johnson, "Radiation modes and the active control of sound power", J. Acoust. Soc. Am. 94, (1993), pp. 2194-2204.

[18] K. A. Cunefare and M. N. Currey, "On the exterior acoustic radiation modes of structures", J. Acoust. Soc. Am. 96, (1994), pp. 2302-2312.

[19] G. V. Borgiotti and K. E. Jones, "Frequency independence property of rqadiation spatial filters", J. Acoust. Soc. Am. 96, (1994), pp. 3516-3524.

[20] M. N. Currey and K. A. Cunefare, "The radiation modes of baffled finite plates", J. Acoust. Soc. Am. 98, (1995), pp.1570-1580.

[21] M. E. Johnson and S. J. Elliott, "Active control of sound radiation using volume velocity cancellation", J. Acoust. Soc. Am. 98, (1995), pp.2174-2186.

[22] X. Pan, T. J. Sutton, and S. J. Elliott, "Active control of sound transmission through a double-leaf partition by volume velocity cancellation", J. Acoust. Soc. Am. 104, (1998), pp.2828-2835.

[23] B. S. Cazzolato and C. H. Hansen, "Active control of sound transmission using structural error sensing", J. Acoust. Soc. Am. 104, (1998), pp. 2878-2889.

[24] S. Griffin, C. H. Hansen, and B. S. Cazzolato, "Feedback control of structurally radiated sound into enclosed spaces using structural sensing", J. Acoust. Soc. Am. 106, (1999), pp.2621-2628.

[25] B. S. Cazzolato and C. H. Hansen, "Structural radiation mode sensing for active control of sound radiation into enclosed spaces", J. Acoust. Soc. Am. 106, (1999), pp. 37323735 .
[26] G. P. Gibbs, R. L. Clark, D. E. Cox, and J. S. Vipperman, "Radiation modal expression: Application to active structural acoustic control", J. Acoust. Soc. Am. 107, (2000), pp.332-339

[27] A. P. Berkhoff, "Sensor scheme design for active structural acoustic control", J. Acoust. Soc. Am. 108, (2000), pp. 1037-1045.

[28] K. A. Cunefare, M. N. Currey, M. E. Johnson, and S. J. Elliott, "The radiation efficiency grouping of free-space acoustic radiation modes", J. Acoust. Soc. Am. 109, (2001), pp. 203-215.

[29] P. Gardonio, Y. S. Lee, and S. J. Elliott, "Analysis and measurement of matched volume velocity sensor and uniform fource actuator for active structural acoustic control", J. Acoust. Soc. Am. 110, (2001), pp.3025-3031.

[30] C. Maury, P. Gardonio, and S. J. Elliott, "Active control of the flow-induced noise transmitted through a panel", AIAA J. 39, (2001), pp.1860-1867.

[31] A. P. Berkhoff, "Broadband radiation modes: Estimation and active control", J. Acoust. Soc. Am. 111, (2002), pp.1295-1305.

[32] T. Chanpheng, H. Yamada, T. Miyata, and H. Katsuchi, "Application of radiation modes to the problem of low-frequency noise from a highway bridge", Applied Acoustics 65, (2004), pp.109-123

[33] W. P. Engels, O. N. Baumann, and S. J. Elliott, "Centralized and decentralized control of structural vibration and sound radiation", J. Acoust. Soc. Am. 119, (2006), pp.1487-1495. [34] T. Kaizuka and N. Tanaka, "Radiation clusters and the active control of sound transmission into a symmetric enclosure", J. Acoust. Soc. Am. 121, (2007), pp.922-937.

[35] S. D. Snyder and C. H. Hansen, "The design of systems to control actively periodic sound transmission into enclosed spaces, part I: Analytical models", J.Sound and Vib. 170, (1994), pp.433-449.

[36] S. D. Snyder and C. H. Hansen, "The design of systems to control actively periodic sound transmission into enclosed spaces, part II: Mechanisms and trends", J.Sound and Vib. 170, (1994), pp.451-472. 